\title{
Human case of autochthonous West Nile virus lineage 2 infection in Italy, September 2011
}

P Bagnarelli (p.bagnarelli@univpm.it) ${ }^{1}$, K Marinelli ${ }^{1}$, D Trotta ${ }^{1}$, A Monachetti ${ }^{1}$, M Tavio ${ }^{2}$, R Del Gobbo ${ }^{2}$, M R Capobianchi ${ }^{3}$, S Menzo $^{3}$, L Nicoletti ${ }^{4}$, F Magurano ${ }^{4}$, P E Varaldo ${ }^{1}$

1. Università Politecnica Marche, Virology Unit, Department of Biomedical Sciences and Public Health, Ancona, Italy

2. Azienda Ospedaliero-Universitaria Ospedali Riuniti di Ancona, Infectious Disease Unit, Department of Gastroenterology and Transplantation, Ancona, Italy

3. National Institute of Infectious Diseases L.Spallanzani, Rome, Italy

4. Istituto Superiore di Sanitá, Rome, Italy

Bagnarelli P, Marinelli K, Trotta D, Monachetti A, Tavio M, Del Gobbo R, Capobianchi MR, Menzo S, Nicoletti L, Magurano F, Varaldo PE. Human case of autochthonous West Nile virus lineage 2 infection in Italy, September 2011.

Euro Surveill. 2011;16(43):pii=20002. Available online: http://www.eurosurveillance.org/ViewArticle.aspx?Articleld=20002

On 10 September 2011, a patient in his 50 s was admitted to hospital in Ancona, Italy, after six days of high fever and no response to antibiotics. West Nile virus (WNV) infection was suspected after tests to determine the aetiology of the fever were inconclusive. On 20 September, WNV-specific IgM and IgG antibodies were detected in the patient's serum. Genomic sequencing of the viral isolate showed that the virus belonged to WNV lineage 2 .

\section{Case report}

On 4 September 2011, a man in his late 50 in Ancona, Italy, first became unwell, with general malaise and fever (body temperature higher than $39.0^{\circ} \mathrm{C}$ ). For these reasons, his general practitioner (GP) prescribed antibiotics, but as the patient's fever persisted after six days of treatment, he was admitted to hospital (Infectious Disease Unit of the Azienda Ospedaliero-Universitaria Ospedali Riuniti di Ancona). On 10 September, the ward physician reported that the origin of the fever was unknown and that there were no pulmonary or other organ-specific symptoms, except the persistence of a general malaise. A chest examination was normal, as were the laboratory tests (haemocultures, urine cultures, haemocytometer analysis, liver and renal biochemical tests, erythrosedimentation rate, C-reactive protein and blood electrolytes). He did not have neuroinvasive disease. He was discharged on 27 September and has completely recovered.

The patient was a local fisherman who lived in Ancona, close to the harbour on the Adriatic coast. In the month before his symptoms began, he had neither travelled outside the Marche region (where Ancona is the main port) in central Italy, nor had he been at sea.

\section{Virological analysis}

Tests on a blood sample taken from the patient on 13 September (tested at the Ancona Virology Laboratory) excluded cytomegalovirus, Epstein-Barr virus, human immunodeficiency virus and Toscana virus as the cause of the fever.

On 20 September, the same sample was also tested for West Nile virus (WNV), based on a recent protocol adopted by the laboratory for differential diagnosis of meningoencephalitis and for patients with fever of unknown origin in the summer months: WNV serological tests are performed in all patients negative for Toscana virus infection. The sample was found to be positive for WNV-specific IgM and IgG (with index values (signal/cut-off ratio) of $>5.4$ and 2.0, respectively) using the IgM capture DxSelect ELISA and IgG DxSelect ELISA kits (Focus Diagnostics, United States) (Table).

Following the positive ELISA results for WNV, RNA extracted from serum (collected on 13 September) and urine (collected on 21 September) was reverse transcribed and amplified by PCR using an in-house assay that uses degenerate primers designed to recognise a region in the NS 5 gene that is conserved (on the basis of an alignment of database sequences) in most animal and human flaviviruses. In the case of WNV, the resulting PCR product is $273 \mathrm{bp}$ long using the forward primer (5'-TGCATITWCAACATGITGGG-3') and reverse primer (5'-GTRTCCCAICCIGCIGTGTCATC-3').

The patient's serum sample tested negative, while the urine sample was positive. Sequencing the amplified product - in both forward and reverse directions with the same primers used for amplification - showed that the WNV NS5 gene sequence had been amplified.

BLAST analysis of the $273 \mathrm{bp}$ sequence showed highest homology (100\%) to the Nea Santa/Greece/2010 WNV strain detected in Culex pipiens in 2010 [1] as well as to other strains belonging to WNV lineage 2 .

The full genomic sequence of the virus was subsequently obtained from RNA extracted from the patient's 
urine sample of 21 September: this confirmed that the virus was lineage 2 . It also showed $99 \%$ identity to the complete genome of isolate goshawk-Hungary/o4 (10, 380 of 10, 423 nucleotides identical and no gaps) and to the more recent Nea Santa-Greece-2010 (10, 374 of 10,423 nucleotides identical and no gaps) [1-2]. The sequences obtained were submitted to GenBank: the accession numbers are JN797253 (NS5 fragment) and JN858070 (complete genome). The case was notified to the regional health authorities on 23 September and to the Istituto Superiore di Sanità on 26 September.

Another serum sample collected from the patient on 26 September showed an increased WNV-specific IgG antibody titre and a high level of WNV-specific IgM. Plasma collected on the same day was negative for WNV by RT-PCR.

The serum samples collected on 13 and 26 September and the urine sample collected on 21 September were tested at the National Reference Laboratory for WNV surveillance at the Istituto Superiore di Sanità, which confirmed the diagnosis by amplification of a different region of the $\mathrm{NS}_{5}$ gene [3].

Urine and plasma samples collected on 28 September were also tested at the National Institute of Infectious Diseases L.Spallanzani, which further confirmed the diagnosis by amplification of WNV sequences in urine but not in plasma using the cobas TaqScreen West Nile Virus Test (Roche Molecular Diagnostics, United States). The plasma sample was also tested at the National Institute of Infectious Diseases L.Spallanzani for the presence of WNV-specific IgG and IgM by an indirect immunofluorescence assay (Euroimmun, Italy), which indicated high antibody titres. In addition, a microneutralisation assay against both lineage 1 and 2 strains [4] revealed cross-neutralising activity. This does not demonstrate co-circulation of the two lineages; antibodies elicited by one WNV lineage are not expected to be highly lineage-specific, because of extensive antigenic similarity between the lineages.

WNV RNA was still detectable by the in-house RT-PCR analysis at the Ancona Virology Laboratory in the urine sample collected on 29 September, 25 days after symptom onset.

The results of all serological and molecular investigations performed on the patient's samples are shown in the Table.

\section{WNV infection in Italy \\ WNV infections have been reported in both humans and horses since the summer of 2008 in north-eastern Italy [5-8] but until now, as far as we are aware, only WNV lineage 1 infections have been described in the country.}

To the best of our knowledge, WNV infection has never been reported before in horses or other sentinel animals in the Marche region. A possible arthropod reservoir has never been investigated, but given the absence of infection in sentinel animals and the absence of diagnosed cases of WNV meningoencephalitis, the region was considered to be at lower risk than the WNV-affected areas of north-east of the country [9].

In contrast, Toscana virus is endemic in the Marche, as well as in the rest of central Italy, and is routinely investigated in all cases of meningoencephalitis reported in the summer and in patients with fever of unknown origin. Due to the circulation of WNV in the north-east of the country, our laboratory testing algorithm was revised, introducing molecular (in summer 2010) and serological (in summer 2011) assays for the diagnosis of WNV infection. These assays are performed for

\section{TABLE}

Serological and molecular test results on samples from the patient with West Nile virus lineage 2 infection, Italy, September 2011

\begin{tabular}{|c|c|c|c|c|c|c|c|c|}
\hline $\begin{array}{l}\text { Date of sample collection } \\
(2011)\end{array}$ & Sample type & $\begin{array}{c}\text { ELISA } \\
\text { IgG } \\
\text { (index) }^{a}\end{array}$ & $\begin{array}{c}\text { ELISA } \\
\text { IgM } \\
\text { (index) }\end{array}$ & $\begin{array}{c}\text { IFA } \\
\text { IgG } \\
\text { (dilution) }\end{array}$ & $\begin{array}{c}\text { IFA } \\
\text { IgM } \\
\text { (dilution) }\end{array}$ & $\begin{array}{c}\text { MNTA } \\
\text { titre } \\
\text { lineage } 1\end{array}$ & $\begin{array}{c}\text { MNTA } \\
\text { titre } \\
\text { lineage } 2\end{array}$ & RT-PCR ${ }^{c}$ \\
\hline 13 Sep & Serum & 2.00 & $>5.40$ & ND & ND & ND & ND & Negative \\
\hline 21 Sep & Urine & NA & NA & NA & NA & NA & NA & Positive \\
\hline 26 Sep & $\begin{array}{c}\text { Serum (ELISA) } \\
\text { Plasma (RT-PCR) }\end{array}$ & 3.01 & $>5.40$ & ND & ND & ND & ND & Negative \\
\hline 29 Sep & Urine & NA & NA & NA & NA & NA & NA & Positive \\
\hline
\end{tabular}

ELISA: enzyme-linked immonosorbent assay; IFA: immunofluorescence assay; MNTA: microneutralisation assay; NA: not applicable; ND: not done; RT-PCR: reverse-transcription polymerase chain reaction; WNV: West Nile virus.

a An index (signal/cut-off ratio) value of $>1.50$ indicates the presence of IgG antibodies to WNV.

b An index (signal/cut-off ratio) value of $>1.10$ indicates the presence of IgM antibodies to WNV.

Carried out using an in-house protocol that uses degenerate primers designed to recognise a region in the NS 5 gene that is conserved (on the basis of an alignment of database sequences) in most animal and human flaviviruses or, for the samples collected on 28 September 2011, using the cobas TaqScreen West Nile Virus Test, a real-time RT-PCR (Roche Molecular Diagnostics). 
hospitalised patients in the Marche region during the months when mosquitoes and other insect vectors are active, generally from early June to late October. Although tests, carried out at the Ancona Virology Laboratory, are usually performed on blood and cerebrospinal fluid (CSF), we recently detected WNV from urine from a kidney transplant patient with encephalitis in the context of an investigation into WNV transmission through organ transplants (unpublished data): in this transplant patient, the virus was detectable in urine by molecular tests for a longer period than in serum, plasma or CSF, consistent with the fact that the kidney is a well-established site of active WNV replication in animals such as birds, dogs and rodents [10-12]. Persistent replication of the virus in kidneys in humans is supported by studies reporting WNV shedding in urine, not only early post-infection [13], but even years after the initial infection [14], although the issue is still debated [15]. In our modified algorithm, a urine sample - the preferred sample for virus detection - is currently requested from patients whose serological tests for WNV are positive in order to confirm the serological results by detecting WNV RNA.

\section{Discussion}

A number of cases of human WNV infection have been reported over the past few years in Italy [16], but never in or close to the Marche region, with the exception of one infection acquired through a kidney transplant from a donor from an affected region [17]. In the Marche, since the summer of 2010, tests for WNV infection have been performed exclusively for the differential diagnosis of meningoencephalitis cases in the summer months. Since the summer of 2011, WNV serological tests are carried also out for patients with fever of unknown origin who are negative for Toscana virus. Had this diagnostic algorithm not been adopted, the cause of the patient's febrile illness would not have been determined and the WNV lineage 2 strain would not have been identified.

This case report suggests that screening for human cases of WNV infection should be further strengthened in the summer, for cases with neuroinvasive disease and for patients with fever of unknown origin, in regions of the country not previously affected by WNV. It is well known that there is an extensive cross-reactive antibody response to members of the Flavivirus genus, thus molecular tests should be performed to confirm the clinical diagnosis and identify the causative virus.

Our data show that tests to detect WNV RNA in serum or plasma may give false-negative results due to the short duration of viraemia. Urine samples may be more appropriate when looking for the presence of WNV, because of longer shedding and higher viral load. Whole WNV genome reconstruction was also easily achieved from the urine sample.

The clinical presentation of the case here described was relatively mild. However, since this is the first case of WNV lineage 2 infection detected so far in the country, it is not possible to draw any conclusions on the virulence and neurotropism of the viral strain. Investigation of any future cases, as well as molecular analysis of the complete genome, could give further information about the presence of genetic determinants of virulence.

It should be noted, however, that the incidence of meningoencephalitis or fever of unknown origin did not increase this summer in the Ancona province.

Autochthonous WNV human infection has been reported in several European countries this summer, including those of the Mediterranean. As of 20 October 2011, 89 confirmed human cases of West Nile fever have been reported in the European Union (66 in Greece, 13 in Italy and 10 in Romania ) and 149 in neighbouring countries (121 in the Russian Federation, 21 in Israel, 3 in Turkey, 2 in Albania and 2 in the Former Yugoslav Republic of Macedonia) $[18,19]$. Notably, cases of WNV infection in Greece in 2011 occurred in areas that had not been affected in 2010 [19].

The WNV lineage 1 sequences from human infections in 2008 to 2009 in Italy were grouped into a distinct cluster within the western Mediterranean cluster [12], suggesting autochthonous spread of a single virus strain, without de novo introduction. The finding of the case in Ancona described in this report might suggest that viral strains circulating in other European countries during this summer might be spreading to Italy. It is possible that the lineage 2 virus reached Ancona via infected mosquitoes carried by ships or via birds from the eastern part of Europe. An epidemiological investigation is under way in the Ancona area to identify risk factors for infection and the possible local spread of lineage 2 WNV among insect vectors and birds.

Whatever the origin of the virus, the finding of a case of WNV lineage 2 infection in the country deserves further attention, as it suggests that viral circulation routes may be expanding, and, possibly, that there is an increased opportunity for this lineage 2 virus to adapt to new environments and ecological niches. It will be important to determine whether the present molecular diagnostic assays, designed mainly to detect lineage 1 WNV, perform equally well for lineage 2 WNV. This may have important implications for effective screening of blood and organ donors.

As a result of this case of WNV infection, the same precautionary measures in force in the WNV-affected regions in north-east Italy were immediately adopted in the Marche, for the sake of safety of organ donation in the region. In particular, these measures concern the need to use a nucleic acid amplification test (NAAT) to check for the presence of WNV RNA in blood taken from organ donors living in the Marche region or who stayed at least one night in the region in the 28 days before notification of the case described in this report. 
In conclusion, stronger vector control programmes, integrated human and animal WNV surveillance and implementation of diagnostic procedures that include testing of urine samples for WNV detection could provide a useful contribution to controlling WNV spread and human disease.

\section{References}

1. Papa A, Bakonyi T, Xanthopoulou K, Vázquez A, Tenorio A, Nowotny N. Genetic characterization of West Nile virus lineage 2, Greece, 2010. Emerg Infect Dis. 2011;17(5):920-2.

2. Bakonyi T, Ivanics E, Erdélyi K, Ursu K, Ferenczi E, Weissenböck $\mathrm{H}$, et al.. Lineage 1 and 2 strains of encephalitic West Nile virus, central Europe. Emerg Infect Dis. 2006;12(4):618-23.

3. Tanaka M. Rapid identification of flavivirus using the polymerase chain reaction. J Virol Methods. 1993;41(3):311-22.

4. Capobianchi MR, Sambri V, Castilletti C, Pierro AM, Rossini G, Gaibani P, et al. Retrospective screening of solid organ donors in Italy, 2009, reveals unpredicted circulation of West Nile virus. Euro Surveill. 2010;15(34):pii=19648 Available from: http://www.eurosurveillance.org/ViewArticle. aspx?Articleld $=19648$

5. Rossini G, Cavrini F, Pierro A, Macini P, Finarelli AC, Po C, et al. First human case of West Nile virus neuroinvasive infection in Italy, September 2008 - case report. Euro Surveill. 2008;13,(41):pii=19002. Available from: http://www. eurosurveillance.org/ViewArticle.aspx?Articleld=19002

6. Barzon L, Squarzon L, Cattai M, Franchin E, Pagni S, Cusinato $\mathrm{R}$, et al. West Nile virus infection in Veneto region, Italy, 2008-2009. Euro Surveill. 2009;14(31):pii=19289. Available from: http://www.eurosurveillance.org/ViewArticle. aspx?Articleld=19289

7. Macini P, Squintani G, Finarelli AC, Angelini P, Martini E, Tamba $M$, et al. Detection of West Nile virus infection in horses, Italy, September 2008. Euro Surveill. 2008;13(39):pii=18990. Available from: http://www.eurosurveillance.org/ViewArticle. aspx?Articleld $=18990$

8. Rizzo C, Vescio F, Declich S, Finarelli AC, Macini P, Mattivi A, et al. West Nile virus transmission with human cases in Italy, August - September 2009. Euro Surveill. 2009;14(40):pii=19353. Available from: http://www. eurosurveillance.org/ViewArticle.aspx?Articleld=19353

9. Ministero della Salute Italiana. Sorveglianza dei casi umani delle malattie trasmesse da vettori con particolare riferimento alla Chikungunya, Dengue e West Nile Disease - 2011 [Surveillance of human cases of vector-borne diseases with special reference to Chikungunya, dengue fever and West Nile disease - 2011]. Ministero della Salute Italiana: Rome; June 2011. Italian. Available from: http://www.normativasanitaria. it/normsan-pdf/0000/39170_1.pdf

10. Komar N, Langevin S, Hinten S, Nemeth N, Edwards E, Hettler $D$, et al. Experimental infection of North American birds with the New York 1999 strain of West Nile virus. Emerg Infect Dis. 2003;9:311-22.

11. Buckweitz S, Kleiboeker S, Marioni K, Ramos-Vara J, Rottinghaus A, Schwabenton B, et al. Serological, reverse transcriptase-polymerase chain reaction, and immunohistochemical detection of West Nile virus in a clinically infected dog. J Vet Diagn Invest. 2003;15(4):324-9.

12. Tonry JH, Xiao SY, Siirin M, Chen H, da Rosa AP, Tesh RB. Persistent shedding of West Nile virus in urine of experimentally infected hamsters. Am J Trop Med Hyg. 2005;72(3):320-4.

13. Tonry JH, Brown CB, Cropp CB, Co JK, Bennett SN, Nerurkar VR, et al. West Nile virus detection in urine. Emerg Infect Dis. 2005;11(8):1294-6.

14. Murray K, Walker C, Herrington E, Lewis JA, McCormick J, Beasley DW, et al. Persistent infection with West Nile virus years after initial infection. J Infect Dis. 2010;201(1):2-4.

15. Gibney KB, Lanciotti RS, Sejvar JJ, Nugent CT, Linnen JM, Delorey MJ, et al. West Nile Virus RNA not detected in urine of 40 people tested 6 years After acute West Nile virus disease. Infect Dis. 2011;203(2):344-7.

16. Rossini G, Carletti F, Bordi L, Cavrini F, Gaibani P, Landini MP, et al. Phylogenetic analysis of West Nile Virus isolates, Italy, 2009-2009.. Emerg Infect Dis. 2011;17(5):903-6.

17. Nanni Costa A, Capobianchi MR, Ippolito G, Palù G, Barzon L, Piccolo G, et al. West Nile virus: the Italian national transplant network reaction to an alert in the north-eastern region, Italy 2011. Euro Surveill. 2011;16(41): pii=19991.
Available from: http://www.eurosurveillance.org/ViewArticle. aspx?Articleld $=19991$

18. European Centre for Disease Prevention and Control (ECDC). West Nile fever maps. Reported cases of West Nile fever for the EU and neighbouring countries. Stockholm: ECDC. [Accessed 20 Oct 2011]. Available from: http://ecdc.europa.eu/en/ activities/diseaseprogrammes/emerging_and_vector_borne diseases/Pages/West_Niles_fever_Risk_Maps.aspx

19. Danis K, Papa A, Papanikolaou E, Dougas G, Terzaki I, Baka A, et al. Ongoing outbreak of West Nile virus infection in humans, Greece, July to August 2011. Euro Surveill. 2011;16(34):pii=19951. Available from: http://www. eurosurveillance.org/ViewArticle.aspx?Articleld=19951 